\title{
Soil Carbon Storage in Silvopastoral Systems and a Treeless Pasture in Northwestern Spain
}

\author{
David S. Howlett, ${ }^{*}$ M. Rosa Mosquera-Losada, P.K. Ramachandran Nair, Vimala D. Nair, and Antonio Rigueiro-Rodríguez
}

Soil particle size and land management practices are known to have considerable influence on carbon (C) storage in soils, but such information is lacking for silvopastoral systems in Spain. This study quantified the amounts of soil C stored at various depths to $100 \mathrm{~cm}$ under silvopastoral plots of radiata pine (Pinus radiata D. Don) and birch (Betula pendula Roth) in comparison to treeless pasture in Galicia, Spain. Soils were fractionated into three size classes $(<53,53-250$, and $250-2000$ $\mu \mathrm{m})$, and $\mathrm{C}$ stored in them and in the whole (nonfractionated) soil was determined. Overall, the $\mathrm{C}$ stock to $1 \mathrm{~m}$ ranged from 80.9 to $176.9 \mathrm{Mg} \mathrm{ha}^{-1}$ in these soils. Up to $1 \mathrm{~m} \mathrm{depth}, 78.82 \%$ of $\mathrm{C}$ was found in the 0 - to $25-\mathrm{cm}$ soil depth, with $12.9,4.92$, and $3.36 \%$ in the $25-$ to $50-, 50$ - to $75-$, and $75-$ to $100-\mathrm{cm}$ depths, respectively. Soils under birch at 0 to $25 \mathrm{~cm}$ stored more $\mathrm{C}$ in the 250 - to $2000-\mu \mathrm{m}$ size class as compared with those under radiata pine; at that depth, pasture had more $\mathrm{C}$ than pine silvopasture in the smaller soil fractions $(<53$ and $53-250 \mu \mathrm{m})$. In the 75 - to $100-\mathrm{cm}$ depth, there was significantly more storage of $\mathrm{C}$ in the 250 - to $2000-\mu \mathrm{m}$ fraction in both silvopastures as compared with the pasture. The higher storage of soil $\mathrm{C}$ in larger fraction size in lower soil depths of silvopasture suggests that planting of trees into traditional agricultural landscapes will promote longer-term storage of $\mathrm{C}$ in the soil.
Copyright $\odot 2011$ by the American Society of Agronomy, Crop Science Society of America, and Soil Science Society of America. All rights reserved. No part of this periodical may be reproduced or transmitted in any form or by any means, electronic or mechanical, including photocopying, recording, or any information storage and retrieval system, without permission in writing from the publisher.

J. Environ. Qual. 40:825-832 (2011)

doi:10.2134/jeq2010.0145

Published online 10 Jan. 2011.

Received 1 Apr. 2010.

*Corresponding author (davhowlett@yahoo.com).

(c) ASA, CSSA, SSSA

5585 Guilford Rd., Madison, WI 53711 USA
A GROFORESTRY HAS BEEN IDENTIFIED as a promising land use for the sequestration of C (Lal, 2004; Sharrow and Ismail, 2004; Nair et al., 2010). Haile et al. (2008) demonstrated greater C storage in deeper soils in silvopasture compared with treeless pastures on Spodosols in Florida. Takimoto et al. (2009) also found greater $\mathrm{C}$ storage in soils underlying improved tree-based practices, such as live fencing and fodder bank agroforestry, than in unimproved systems in the West African Sahel region of Mali. While tree-based agroforestry systems are a preferred method for aboveground biomass $\mathrm{C}$ sequestration as compared to treeless pastures, there is evidence that $\mathrm{C}$ storage in deep soil horizons is greater (Takimoto et al., 2009; Haile et al., 2010; Saha et al., 2010). Silvopasture, a mix of grass and tree components on the same land, offers extra productive and environmental benefits (including $\mathrm{C}$ storage) in addition to those provided by grass-based systems alone.

Carbon inputs to the soil from root decay and leaf fall are broken down by macro and micro fauna. Most $\mathrm{C}$ is lost in this process of decay, but some residual $\mathrm{C}$ becomes incorporated into the soil, humified, and eventually ends up in longer-term soil $\mathrm{C}$ pools. Over time, these resistant $\mathrm{C}$ pools can become quite large (Rodríguez-Murillo, 2001). The mean residence time for soil organic C varies as a function of aggregate size class (Parton et al., 1987; Six et al., 2002a). Carbon associated with macroaggregate $(250-2000 \mu \mathrm{m})$, microaggregate $(53-250 \mu \mathrm{m})$, and silt+clay $(<53$ $\mu \mathrm{m})$ size soil fractions can have a mean residence time of 1 to 10 , 25, and 100 to 1000 yr, respectively (Parton et al., 1987; Schimel et al., 1994). Several studies have proposed that long-term storage of $\mathrm{C}$ can occur in soil aggregates (Balesdent et al., 1998; Jastrow and Miller, 1998; Six et al., 2002b; Blanco-Canqui and Lal, 2004) and specifically within microaggregates and silt+clay aggregates formed within macroaggregates. The shift from till to no-till land use practices leads to the preferential formation of macroaggregates, which are made up by microaggregates and smaller siltclay sized aggregates (Christensen, 2001; Six et al., 2002b). This hierarchical organization of smaller-sized aggregates within larger aggregates protects $\mathrm{C}$ stored in each occluded size fraction from microbial attack (Jastrow and Miller, 1998; Christensen, 2001). The loss of $\mathrm{C}$ generally occurs where tillage is implemented on previously untilled soils (Guo and Gifford, 2002) because tillage

D.S. Howlett and P.K.R. Nair, Center for Subtropical Agroforestry, School of Forest Resources and Conservation, P.O. Box 110410, Univ. of Florida, Gainesville, FL 32611; M.R. Mosquera-Losada and A. Rigueiro-Rodríguez, Departamento de Producción Vegetal, Escuela Politécnica Superior de Lugo, Universidad de Santiago de Compostela; Campus Universitario s/n, 27002 Lugo, Spain; V.D. Nair, Soil and Water Science Dep., P.O. Box 110510, Univ. of Florida, Gainesville, FL 32611. Assigned to Associate Editor John Kort.

Abbreviations: SOC, soil organic carbon. 
disrupts the process of macroaggregate formation, increasing bioavailable sources of $\mathrm{C}$ from smaller aggregates (Six et al., 2000). The physical fractionation of soils into size class fractions allows us to consider the effect different land use practices have on the process of soil aggregation, how much $\mathrm{C}$ is contained in each fraction, and an estimation of residence times of soil organic C (SOC) in a given soil (Christensen, 2001). In particular, the formation of macroaggregates, and thus the formation of stable microaggregates within, is affected by land management (tillage, afforestation, etc.), which is an indicator of potential long-term storage of SOC (Six et al., 2000).

As a signatory to the Kyoto Protocol, Spain seeks to limit emissions of greenhouse gases, especially $\mathrm{CO}_{2}$. Accurate accounting of soil $\mathrm{C}$ sequestration will enable Spain to determine if soils are a source or sink for atmospheric C. Current land use and vegetation types in Spain, including forests and agricultural lands, are major indictors of stored C (RodríguezMurillo, 2001). Land use in the northwestern region of Galicia, Spain is shifting, as traditional row crops and pastures are being converted to mostly short-rotation exotic tree plantations or are abandoned (Zas and Alonso, 2002; Marey-Pérez and Rodríguez-Vicente, 2008). Silvopasture may be a preferred alternative to wholesale conversion to forest plantation in Galicia for a host of benefits, including reduced fire risk.

The objectives of the study were (i) to quantify and compare the amount of $\mathrm{C}$ stored in the whole soil and three differently sized soil fractions $(<53,53-250$, and 250-2000 $\mu \mathrm{m})$ underlying a simulated silvopasture experiment, (ii) to compare the amount of $\mathrm{C}$ stored in the whole soil and three differently sized soil fractions in silvopasture plots with an adjacent treeless pasture at each of four soil depths, and (iii) to calculate the SOC storage to $1 \mathrm{~m}$ depth for all silvopasture experimental treatment combinations and an adjacent pasture. This study was undertaken to demonstrate the effects that tree presence, tree species, tree spacing, and fertilization have on soil C storage.

\section{Materials and Methods}

\section{Study Site}

The study was performed at the Castro de Rey Farm, located approximately $12 \mathrm{~km}$ north of the city of Lugo in the region of Galicia, Spain $\left(43^{\circ} 9^{\prime} 39^{\prime \prime} \mathrm{N}, 7^{\circ} 29^{\prime} 54^{\prime \prime}\right.$ W; $440 \mathrm{~m}$ a.s.l.). Mean rainfall in this region is $1080 \mathrm{~mm} \mathrm{yr}^{-1}$, and the mean annual temperature is $11.5^{\circ} \mathrm{C}$ (range, $5.8-18^{\circ} \mathrm{C}$ from January to August). The majority of precipitation falls from October to April. Soils are gleyic Umbrisols (FAO classification) and Inceptisols (USDA system); sandy loam, with an increase in clay below $50 \mathrm{~cm}$; organic horizons reaching down to $40 \mathrm{~cm}$; and acidic with no accumulations of inorganic $\mathrm{C}$ (Fernández-Núñez, 2007). The seasonal high water table is at approximately $60 \mathrm{~cm}$ depth. The climate is influenced by Atlantic climatic patterns, with long cool moist winters and warm dry summers, with soil moisture becoming limiting in late summer (EEA, 2006).

\section{Silvopasture Experimental Plots and Soil Sampling Locations}

The silvopastoral research plots at the Castro de Rey Farm were initiated in 1995 to study the effects of fertilizer treatments on the growth of the Orchard grass (Dactylis glomerata L.) planted under radiata pine (Pinus radiata D. Don) and European birch (Betula pendula Roth). In each plot, 25 individual trees each were planted in five rows of five in two different spacings $(2 \times 2$ $\mathrm{m}$ and $3 \times 4 \mathrm{~m}$ ), forming two sizes of plots (64 or $192 \mathrm{~m}^{2}$ in area) at the farm. All tree measures and soil sampling were completed within the interior $3 \times 3$ grid of trees $(n=9)$ within the $5 \times 5$ parcels to reduce edge effects. Plots were fertilized with one of three different treatments (Rigueiro-Rodríguez et al., 2000; Mosquera-Losada et al., 2006): (i) Mineral fertilizer alone, according to local recommendations of (per hectare) 40 $\mathrm{kg} \mathrm{N}, 120 \mathrm{~kg}$ P, $80 \mathrm{~kg} \mathrm{~K}$ in March, with calcium ammonium nitrate $(10.4 \mathrm{~kg} \mathrm{~N} ; 3.2 \mathrm{~kg} \mathrm{Ca})$ applied in May of each year of the experiment; (ii) biosolids fertilizer, approximately $154 \mathrm{~m}^{3}$ ha $^{-1}$, per hectare equivalents $\left(200 \mathrm{~kg} \mathrm{~N}, 85.9 \mathrm{~kg} \mathrm{P}_{2} \mathrm{O}_{5}, 23.4 \mathrm{~kg}\right.$ $\mathrm{K}_{2} \mathrm{O}, 256.6 \mathrm{~kg} \mathrm{CaO}$, and $32.8 \mathrm{~kg} \mathrm{MgO}$ ), dairy residue sludge application made in the establishment year (1995) and then mineral fertilizer applied annually since 1998; and (iii) no fertilizer application (control).

The silvopasture understory was established at the same time as trees, with a seed mix of D. glomerata L. var. Saborto $\left(25 \mathrm{~kg} \mathrm{ha}^{-1}\right)$, Trifolium repens $\mathrm{L}$. group Ladino $\left(4 \mathrm{~kg} \mathrm{ha}^{-1}\right)$, and Trifolium pratense $\mathrm{L}$. var. Marino $\left(1 \mathrm{~kg} \mathrm{ha}^{-1}\right)$. An immediately adjacent pasture (not managed for research) was established at the same time with a commonly used local mix of $T$. repens Huia $\left(2 \mathrm{~kg} \mathrm{ha}^{-1}\right)$, D. glomerata L. var. Saborto $\left(10 \mathrm{~kg} \mathrm{ha}^{-1}\right), T$. repens L. group Ladino $\left(1 \mathrm{~kg} \mathrm{ha}^{-1}\right)$, and Lolium perenne L. (10 $\left.\mathrm{kg} \mathrm{ha}^{-1}\right)$. Pasture grasses and silvopasture understory were harvested and removed mechanically twice a year. Because there is no animal component removing forage or adding feces in this system, these experimental plots are considered simulated silvopasture. Before initiation of the experiment in 1995, the site (silvopasture experiments and adjacent pasture) was under potato (Solanum tuberosum L.) cultivation for more than 30 yr (Rigueiro-Rodríguez et al., 2000; Mosquera-Losada et al., 2006; Fernández-Núnez et al., 2010). The pasture under radiata pine had not been fertilized since 2001, but from 1995 to 2001 in radiata pine and from 1995 to 2005 in birch, plots were annually fertilized with (per hectare) $40 \mathrm{~kg} \mathrm{~N}, 120 \mathrm{~kg}$ P, and $80 \mathrm{~kg} \mathrm{~K}$. In the adjacent pasture, six evenly spaced sampling points were randomly chosen along a parallel transect line approximately $20 \mathrm{~m}$ to the south of the silvopasture experiments. The pasture has not been fertilized since 2001 but from 1995 to 2001 was annually fertilized, per hectare, with $36 \mathrm{~kg}$ N, $108 \mathrm{~kg}$ P, and $73 \mathrm{~kg} \mathrm{~K}$.

\section{Soil Sampling, Preparation, and Analysis}

Soil samples were removed from the site in January 2008 using a stainless steel cylinder with a cutting edge that was inserted with a powered hammer and removed with a platform-stabilized pulley (Moreno et al., 2005). Soil cores were divided in the field into four subsamples corresponding to four sampling depths $(0-25,25-50,50-75$, and $75-100 \mathrm{~cm})$. Soil bulk density was separately determined across treatment combinations for each sampling depth interval; soil was collected by a mallet-inserted cylinder of a known volume from holes dug in the plots, dried at $105^{\circ} \mathrm{C}$ for $48 \mathrm{~h}$ and weighed, and the dry soil mass was divided by the volume of soil collected $\left(\mathrm{g} \mathrm{cm}^{-3}\right)$. Trees were measured within $4 \mathrm{wk}$ of soil sampling for diameter at breast height 
(1.3 $\mathrm{m}$ above ground) and overall height. Mortality of trees was noted in each of the treatment plots.

Soil samples were air dried at room temperature ( 20$25^{\circ} \mathrm{C}$ ) to a constant weight and passed through a 2-mm sieve (\#10 U.S. Standard Testing Sieve). The portion of soil that did not pass the 2-mm sieve was separated, dried overnight at $70^{\circ} \mathrm{C}$ (with the weight noted), and discarded. The weight of the discarded fraction would be used to convert the eventual data derived from the 2-mm sieved fraction (hereafter referred to as "whole soil") back to field conditions (Rodríguez-Murillo, 2001; Six et al., 2002a). Whole soil samples were ground for homogenization and analyzed by a LECO C.N.H.S. Elemental Analyzer (LECO, St. Joseph, MI) for percentage C within $2 \mathrm{wk}$ of being air dried. Particle size analysis was completed on a subsample of whole soil using the pipette method (Soil Survey Staff, 2004). Soil pH was measured in $0.1 \mathrm{~mol} \mathrm{~L}^{-1} \mathrm{KCl}$ using a Crison $\mathrm{pH}$ meter at $20^{\circ} \mathrm{C}$ (Crison Corp., Barcelona, Spain).

\section{Soil Fractionation and Carbon Determination}

The whole soil was physically fractionated according to Elliott (1986) and Six et al. (2002b). A 25-g sample of 2-mm sieved air-dried soil of known moisture content was placed in a 250 -mL beaker. Distilled water $(\sim 150 \mathrm{~mL})$, enough to completely cover the soil, was poured into the beaker to promote slaking. The slaking process breaks up water-unstable aggregates in the soil, leaving water-stable aggregates for further analysis. After $5 \mathrm{~min}$, using 250 - and $53-\mu \mathrm{m}$ sieves (\#60 and \#270 U.S. Standard Testing Sieves, respectively), slaked soil was poured on top of the $250-\mu \mathrm{m}$ sieve. Soil solution was wetsieved manually by moving the sieve up and down about $5 \mathrm{~cm}$ each, 50 times in $2 \mathrm{~min}$. What did not pass the $250-\mu \mathrm{m}$ sieve was backwashed, with a distilled water-filled wash bottle, into a preweighed and numbered aluminum plate. The remaining soil solution was poured over the $53-\mu \mathrm{m}$ sieve and given the same 2-min manual sieving. What did not pass the $53-\mu \mathrm{m}$ sieve was backwashed into a preweighed and numbered aluminum plate. The remaining soil solution that passed the $53-\mu \mathrm{m}$ sieve was poured into a preweighed and numbered aluminum plate. The three soil fractions $(250-2000,53-250$, and $<53 \mu \mathrm{m})$ were dried at $60^{\circ} \mathrm{C}$ overnight, weighed, ground for homogenization, and stored in individually sealed and labeled plastic bags for further C analysis. Samples were then analyzed by a LECO C.N.H.S. Elemental Analyzer for percentage C within $2 \mathrm{wk}$ after whole soil was air dry. Laboratory analysis was conducted at the University of Santiago de Compostela, Crop Production Department laboratories in Lugo, Galicia, Spain. Texture was determined at the University of Florida, Soil and Water Science Department laboratories in Gainesville, Florida.

\section{Experimental Design and Statistical Analysis}

The silvopastoral experiments were laid out as a completely randomized block with two tree species (radiata pine and European birch), two tree spacing $(2 \times 2$ and $3 \times 4 \mathrm{~m})$, and three fertilization regime (mineral, biosolids, and no fertilizer control) as treatment factors, with three replicates of each for a total of 36 plots. Each treatment combination was compared with an adjacent treeless pasture ( $n=6$ replicates) for a total of 42 plots under study. Soil samples were taken from four depths and separated into the whole soil and three soil fractions, from which analysis of soil C was completed. Data for statistical analysis were stored and organized using Microsoft Excel, and ANOVA for treatment factors were completed using SAS statistical software version 9.2 for Windows (SAS Corporation, Carey, NC). Bulk density of the soil, measured at each sampling depth, was found to not vary among treatment combinations and was used to convert $\mathrm{C}$ concentrations in the whole soil and fractions to $\mathrm{MgC} \mathrm{ha}{ }^{-1}$ for each depth interval (0-25, $25-50,50-75$, and $75-100 \mathrm{~cm}$ ) using the following formula:

$$
\begin{aligned}
& \left(\frac{\mathrm{g} \mathrm{C}}{\mathrm{g}<2 \mathrm{~mm} \text { soil }}\right) \times\left(\frac{\mathrm{g}<2 \mathrm{~mm} \text { soil }}{\mathrm{g} \text { bulk soil }}\right) \times\left(\frac{\mathrm{g} \text { bulk soil }}{\mathrm{cm}^{3}}\right) \\
& \times\left(\frac{\mathrm{g} \text { fraction soil }}{\mathrm{g}<2 \mathrm{~mm} \text { soil }}\right) \times\left(\frac{25 \mathrm{~cm}}{1}\right) \times\left(\frac{100}{1}\right)=\mathrm{MgCha}^{-1}
\end{aligned}
$$

The weight of soil fractions was calculated as a percentage of total whole soil weight. Mean C storage in soil fractions on a per hectare basis and percentage fraction recovery from wet sieving were compared using proc GLM in SAS. Data were log transformed to meet normality requirements for ANOVA. Means reported here were converted from log-transformed data.

Within the silvopasture experiment, an ANOVA was performed for each of the following treatment factors for each soil fraction: soil depth, fertilizer type, tree species, and spacing. Carbon storage in the soil fractions at each sampling depth was compared for pooled treatment combinations: radiata pine versus birch versus pasture; biosolid, mineral, and control fertilizer versus pasture; and for the $3 \times 4 \mathrm{~m}$ and $2 \times 2 \mathrm{~m}$ spacing treatments for each species of tree versus pasture. We have limited our discussion to the main effects (land use cover type) and do not address the effect that varying levels of fertilizer and tree spacing have on mean SOC storage. Mean separation was completed using the Tukey's HSD multiple range test, with $\alpha<0.05$.

\section{Results}

Tree height, diameter, and mortality from the simulated silvopasture experiment are given in Table 1. Soil depth and tree species had significant effects on soil C stocks in all soil fractions (Table 2). Additionally, the spacing by fertilizer and spacing by tree species interactions were significant. To $1 \mathrm{~m}$ depth, the vast majority of soil C $(78.8 \%)$ was found in the 0 - to $25-\mathrm{cm}$ soil depth, with $12.9 \%$ in the 25 - to $50-\mathrm{cm}$ depth, $4.9 \%$ in the 50 - to $75-\mathrm{cm}$ depth, and $3.4 \%$ in the $75-$ to $100-\mathrm{cm}$ depth.

The whole soil underlying birch had higher $\mathrm{C}$ than under radiata pine at the 0 - to $25-\mathrm{cm}$ depth (Fig. 1). All other depths had statistically similar $\mathrm{C}$ stock. No significant differences were identified in mean soil $\mathrm{C}$ under birch and radiata pine with three fertilizer treatments and the adjacent pasture or for mean soil $\mathrm{C}$ under the two tree species in two spacing treatments and the adjacent pasture at any depth (Fig. 1).

For the 250- to 2000- $\mu \mathrm{m}$ fraction, soil under birch had more $\mathrm{C}$ than pasture and radiata pine at 0 to $25 \mathrm{~cm}$; birch had also more $\mathrm{C}($ at $p<0.05)$ than pasture at the lowest depth of 75 to $100 \mathrm{~cm}$. Carbon in this fraction underlying radiata pine stands was not significantly different from that in the adjacent pasture, except at the $75-$ to $100-\mathrm{cm}$ depth (Fig. 1). Significantly greater $\mathrm{C}$ storage in the 75 - to $100-\mathrm{cm}$ depth was found for 
mineral fertilizer (including no fertilizer) treatment for birch as compared with pasture (data not shown). Nonfertilized radiata pine treatments also had significantly greater $\mathrm{C}$ storage in this fraction than the adjacent pasture. As for spacing contrasts, birch at $3 \times 4 \mathrm{~m}$ spacing showed more $\mathrm{C}$ through at all sampling depths, with significantly more $\mathrm{C}$ as compared with the pasture at all except the 25- to 50-cm depth (data not shown). The $2 \times 2$ $\mathrm{m}$ birch silvopasture treatments had similar $\mathrm{C}$ storage as the pasture across most sample depths, except the $50-$ to $75-\mathrm{cm}$ depth. As for radiata pine spacing treatments, the $2 \times 2 \mathrm{~m}$ spacing had, in general, more $\mathrm{C}$ at the two lowest sampling depths.

For the 53- to 250- $\mu \mathrm{m}$ soil fraction, soil under pasture had more $\mathrm{C}$ storage in the upper soil layers (to $50 \mathrm{~cm}$ depth) than radiata pine and had statistically similar storage as under birch (Fig. 1); no differences between treatments were noted below $50 \mathrm{~cm}$ depth (Fig. 1). Carbon storage was similar at all depths under birch, but, under pasture, it was greater in the shallower sampling depths $(0-50 \mathrm{~cm})$ than under the $3 \times 4 \mathrm{~m}$ radiata pine spacing treatment yet was statistically similar to the dense $2 \times 2$ $\mathrm{m}$ spacing treatment in all sampling depths (data not shown).

Overall, pasture had more $\mathrm{C}$ than both tree species in the $<53-\mu \mathrm{m}$ soil fraction in the 0 - to $25-\mathrm{cm}$ depth and more $\mathrm{C}$ in the 25 - to $50-\mathrm{cm}$ depth than radiata pine (Fig. 1). In the two lower depths $(50-100 \mathrm{~cm})$, no differences were found among pooled species treatments. On an area basis (per ha), among all treatment combinations, birch planted at $3 \times 4 \mathrm{~m}$ spacing with no fertilizer showed significantly greater $\mathrm{C}$ storage than the radiata pine at an identical management regime (spacing and fertilizer) (176.91 versus $80.94 \mathrm{Mg} \mathrm{C} \mathrm{ha}^{-1}$, respectively, at $p<0.05)$. All other treatment combinations were statistically similar (Table 3).

\section{Discussion}

\section{Simulated Silvopasture Experiment}

Within the simulated silvopasture experiment at the Castro de Rey Farm (excluding the adjacent pasture), soil depth and tree species were significant factors in soil C storage in each of the soil fractions (Table 2). The predominance of SOC found in upper soil horizons is consistent with worldwide trends (Jobbagy and Jackson, 2000). Another significant main treatment factor that determined SOC storage is tree species (Table 2). Kasel and Bennett (2007) found a 30\% decrease in SOC as native broadleaf forests (Eucalyptus spp.) were converted to exotic pine plantations in temperate Australia. Conversion of cropland (as is the case at the Castro de Rey Farm) to broadleaf

Table 1. A comparison of mean height, diameter at breast height, and mortality for Pinus radiata and Betula pendula for each combination of two spacing treatments and three fertilizer treatments at the Castro de Rey Farm, Galicia, Spain.

\begin{tabular}{|c|c|c|c|c|c|}
\hline \multirow{2}{*}{ Tree characteristics } & \multirow{2}{*}{ Fertilizer } & \multicolumn{2}{|c|}{ Pinus radiata } & \multicolumn{2}{|c|}{ Betula pendula } \\
\hline & & $2 \times 2 \mathrm{~m}$ & $3 \times 4 \mathrm{~m}$ & $2 \times 2 \mathrm{~m}$ & $3 \times 4 \mathrm{~m}$ \\
\hline \multirow[t]{3}{*}{ Height, m } & biosolids & 12.34a† (0.88)‡ & $12.17 a(0.42)$ & $7.34 b(0.54)$ & $9.37 a(0.35)$ \\
\hline & mineral & $11.52 \mathrm{a}(0.73)$ & 12.39a (1.05) & $6.61 \mathrm{~b}(1.29)$ & $9.22 \mathrm{a}(0.47)$ \\
\hline & control & $13.37 a(0.52)$ & $13.22 \mathrm{a}(0.58)$ & $7.01 b(0.36)$ & $10.66 a(0.22)$ \\
\hline \multirow[t]{3}{*}{ Diameter, cm } & biosolids & $15.26 \mathrm{~b}(1.59)$ & $19.79 a(1.70)$ & $5.62 b(0.58)$ & 9.93a (0.55) \\
\hline & mineral & $12.21 \mathrm{~b}(1.31)$ & $19.45 a(2.66)$ & $3.63 b(0.93)$ & $10.02 \mathrm{a}(0.83)$ \\
\hline & control & $15.67 \mathrm{~b}(1.04)$ & $22.85 a(1.45)$ & $4.79 b(0.40)$ & $10.56 a(0.43)$ \\
\hline \multirow[t]{3}{*}{ Mortality, \% } & biosolids & 22 & 37 & 37 & 15 \\
\hline & mineral & 37 & 59 & 67 & 7.4 \\
\hline & control & 3.7 & 26 & 22 & 0 \\
\hline
\end{tabular}

† Mean heights and diameters for each tree species followed by different lowercase letters were significantly different using Tukey's HSD at $p<0.05$.

₹ Standard errors of the mean are reported in parentheses.

Table 2. Analysis of variance table for treatment factors (including all interactions) affecting soil carbon storage in the whole soil and three soil fractions in a simulated silvopasture experiment at the Castro de Rey Farm, Galicia, Spain

\begin{tabular}{|c|c|c|c|c|}
\hline \multirow{2}{*}{ Source } & \multicolumn{4}{|c|}{ Soil fraction $p$ values } \\
\hline & Whole soil & $250-2000 \mu \mathrm{m}$ & $53-250 \mu \mathrm{m}$ & $<53 \mu \mathrm{m}$ \\
\hline Depth & $<0.001$ & $<0.001$ & $<0.001$ & $<0.001$ \\
\hline Fertilizer & NSt & NS & NS & NS \\
\hline Spacing & NS & NS & NS & 0.04 \\
\hline Tree species & 0.008 & NS & 0.03 & 0.007 \\
\hline Fertilizer $\times$ depth & NS & NS & NS & NS \\
\hline Spacing $\times$ depth & NS & NS & NS & NS \\
\hline Tree species $\times$ depth & NS & NS & NS & NS \\
\hline Spacing $\times$ fertilizer & 0.008 & 0.0016 & 0.0091 & 0.049 \\
\hline Species $\times$ fertilizer & NS & NS & NS & NS \\
\hline Species $\times$ spacing & $<0.0001$ & $<0.0001$ & $<0.001$ & 0.046 \\
\hline Spacing $\times$ fertilizer $\times$ depth & NS & NS & NS & NS \\
\hline Tree species $\times$ fertilizer $\times$ depth & NS & NS & NS & NS \\
\hline Tree species $\times$ spacing $\times$ depth & NS & NS & 0.01 & NS \\
\hline Tree species $\times$ spacing $\times$ fertilizer & NS & NS & NS & NS \\
\hline
\end{tabular}

† NS, not significant. 
species plantation had little effect on SOC, but conversion of cropland to pine plantations has been shown to significantly decrease SOC (Guo and Gifford, 2002; Kasel and Bennett, 2007). Although species selection for silvopasture establishment clearly had a effect on SOC storage to $1 \mathrm{~m}$ at the Castro de Rey Farm (with birch as the preferred species compared with pine for improving SOC storage), the interactive effect of species versus spacing (Table 2) supersedes the general explanation for differences in soil $\mathrm{C}$ found under each tree species. The $3 \times 4 \mathrm{~m}$ spacing was shown to lead to greater SOC storage in birch than pine in all soil fractions (data not shown). At the $2 \times 2 \mathrm{~m}$ spacing, SOC storage was similar among tree species.

\section{Carbon in Whole Soil and Soil Fractions}

\section{Whole Soil}

Carbon in the whole soil decreased with soil sampling depth, as is typical of many SOC studies (Corre et al., 1999; Paul et al., 2002; Guo et al., 2007; Haile et al., 2008). From the point of view of enhanced soil C sequestration in the whole soil, birch appears to be the preferred tree species as compared with radiata pine (Fig. 1). The difference between pine and broadleaf species has been identified as a major factor affecting SOC storage (Paul et al., 2002). Pine stands create an understory environment that is less conducive to plant growth by the for-
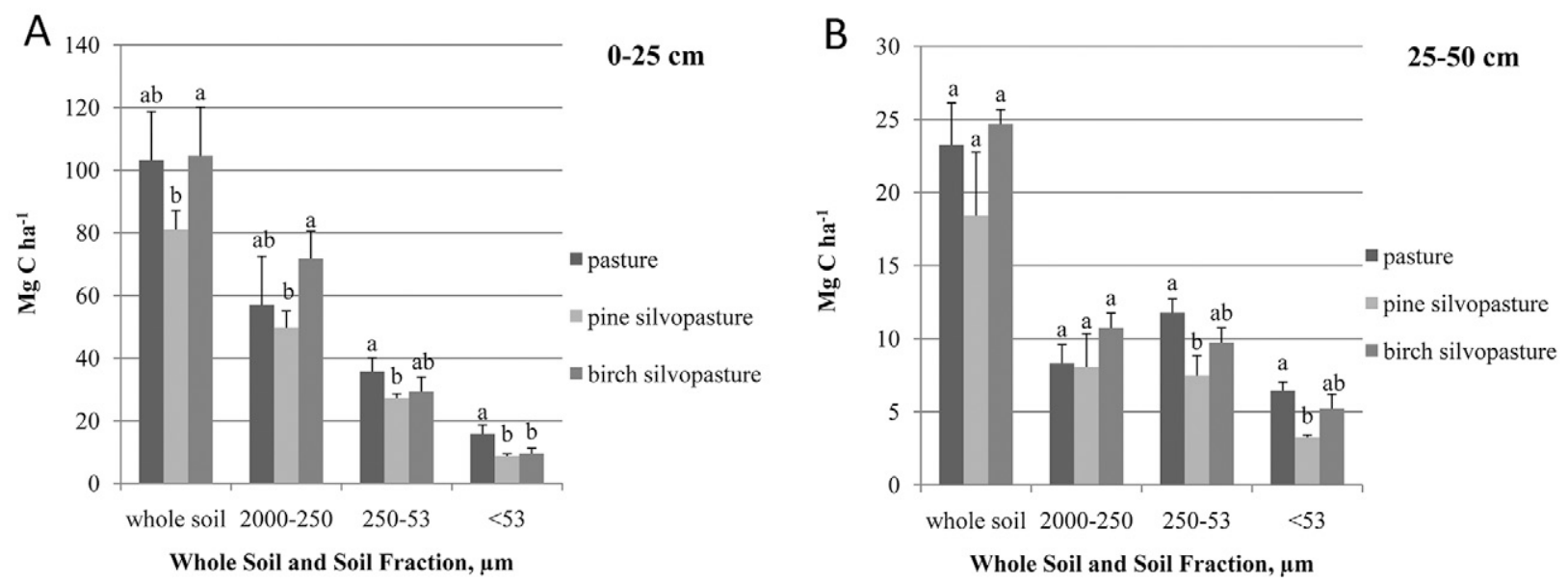

Whole Soil and Soil Fraction, $\mu \mathrm{m}$

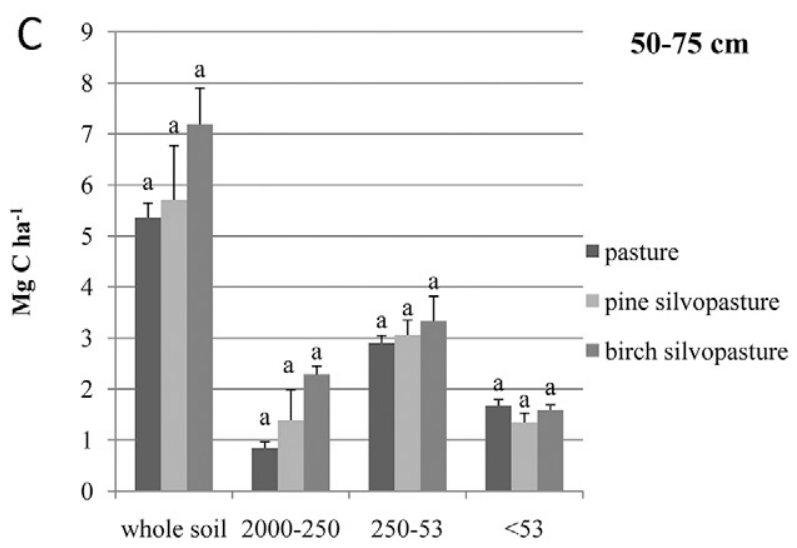

Whole Soil and Soil Fraction, $\mu \mathrm{m}$

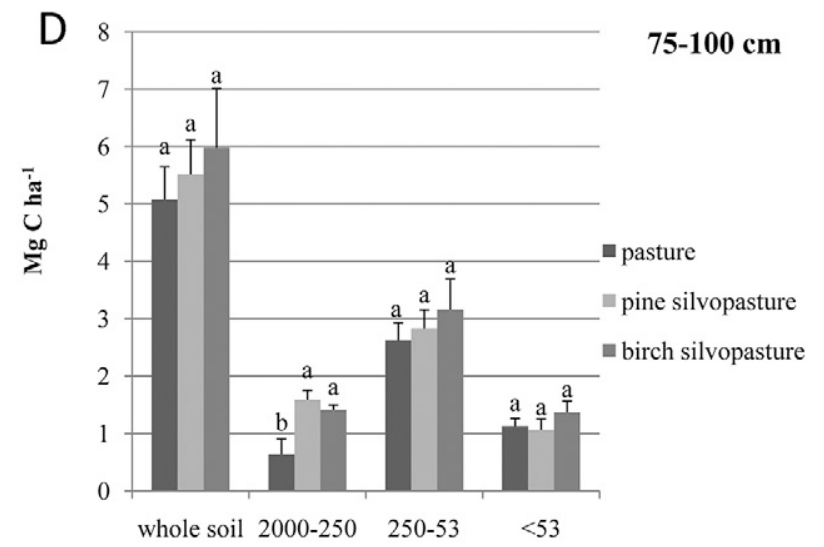

Whole Soil and Soil Fraction, $\mu \mathrm{m}$

Fig. 1. Mean soil carbon storage in whole soil and three soil fractions $(2000-250,250-53$, and $<53 \mu \mathrm{m}$ ) at four depths up to $100 \mathrm{~cm}$ (A: $0-25 \mathrm{~cm}$; B: 25-50 cm; C: 50-75 cm; D: 75-100 cm) under birch and pine silvopastures and a treeless pasture in Galicia, Spain. Means within the whole soil and each soil fraction and depth labeled with different lower-case letters differ statistically by Tukey's HSD at $p<0.05$. Bars represent SEM.

Table 3. Whole-field comparison of mean carbon storage to $100 \mathrm{~cm}$ depth underlying silvopastoral treatments combinations and an adjacent pasture at the Castro de Rey Farm, Galicia, Spain.

\begin{tabular}{|c|c|c|c|c|c|}
\hline \multirow{3}{*}{ Cover } & \multicolumn{5}{|c|}{$\mathrm{SOC}+$ to $100 \mathrm{~cm}$} \\
\hline & \multicolumn{2}{|c|}{ Pinus radiata } & \multicolumn{2}{|c|}{ Betula pendula } & \multirow{2}{*}{$\begin{array}{c}\text { Pasture } \\
\text { None }\end{array}$} \\
\hline & $2 \times 2 \mathrm{~m}$ & $3 \times 4 \mathrm{~m}$ & $2 \times 2 \mathrm{~m}$ & $3 \times 4 \mathrm{~m}$ & \\
\hline & 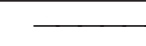 & & $-\mathrm{MgCha}^{-1}$ & +2 & ב \\
\hline Biosolids fertilizer & $122.24 \mathrm{ab} \neq$ & $114.25 \mathrm{ab}$ & $96.28 a b$ & $173.42 \mathrm{ab}$ & - \\
\hline Mineral fertilizer & $135.25 \mathrm{ab}$ & $103.34 \mathrm{ab}$ & 161.18ab & $140.44 a b$ & 132.93ab \\
\hline No fertilizer & $108.04 \mathrm{ab}$ & $80.94 b$ & 105.98ab & $176.91 a$ & - \\
\hline
\end{tabular}

† SOC, soil organic carbon.

₹ Means followed by different lowercase letters differ significantly by Tukey's HSD (at $p<0.05$ ). 
mation of a slowly decomposing duff layer, which inhibits germination and growth of other species and, over time, reduces $\mathrm{C}$ inputs to the soil (Paul et al., 2002). Fernández-Núnez (2007) found an approximately $20-\mathrm{cm}$ layer of pine needles on the site of the current study. The lack of herbaceous species in the pine understory reduces fine root growth and thus $\mathrm{C}$ inputs. Guo et al. (2007) found that soils that had been afforested with $P$. radiata compared with a native pasture in temperate Australia had significantly less overall root length production, shorter turnover rates, and greater longevity down to $60 \mathrm{~cm}$ depth. Birch, as well as other broad-leafed species, are believed to be better at improving $\mathrm{C}$ sequestration by the relatively high $\mathrm{N}$ levels in leaves (thus lower $\mathrm{C}$ to $\mathrm{N}$ ratios) that form inputs to the $\mathrm{SOC}$ (Paul et al., 2002). In the current study, birch had an actively growing understory, and annual measures of forage production were ongoing in January 2008, when sampling for this study was completed. Pine, on the other hand, showed almost no understory growth, especially in the $2 \times 2 \mathrm{~m}$ spacing. In 2000 , understory growth was reduced under both tree species in the $2 \times 2 \mathrm{~m}$ spacing as compared with the $3 \times 4 \mathrm{~m}$ spacing, and by 2006 , understory plant growth was nil under pine in the $2 \times 2$ $\mathrm{m}$ spacing, and under birch forage was still being produced in both spacings (Fernández-Núñez, 2007). The combination of the two silvopasture components-the tree and understory herbaceous species- helps to improve $\mathrm{C}$ inputs to the soil and, as such, can lead to greater $\mathrm{C}$ sequestration in the soil than in pasture and plantation alone (Sharrow and Ismail, 2004). The fertilizer treatments also had no detectable effect on SOC in the whole soil. Theodorou and Bowen (1990) found that fertilizer did increase $P$. radiata growth and needle duff layer but found that mineralization of the $\mathrm{C}$ in the duff was still more controlled by environmental conditions; as such, inputs to the soil were not different from controls. The incorporation of lower lignin-containing birch leaf litter in the soil, as compared with pine (Hobbie et al., 2006), has likely led to greater SOC storage. At the time of sampling for the current study in January 2008, all pine stands were essentially pure plantations, with no growing understory. Although established as silvopastures in 1995, the forage component would likely only be revived with thinning and duff removals. The birch, on the other hand, maintained an herbaceous component and therefore is a preferred species for silvopasture establishment and maintenance and for $\mathrm{C}$ sequestration in the soil.

\section{0- to 2000- $\mu \mathrm{m}$ Fraction}

The 250- to $2000-\mu \mathrm{m}$ size class represented greater soil dry weight in the upper $50 \mathrm{~cm}$ of soil; the proportion of the 53- to $250-\mu \mathrm{m}$ size class increased with soil depth, and, in the $75-$ to $100-\mathrm{cm}$ depth, it was greater than the $250-$ to $2000-\mu \mathrm{m}$ size class in weight (data not shown). Recovery in the smallest $<53$ $\mu \mathrm{m}$ was never more than $10 \%$ by mass at any depth but did increase with depth. Carbon content in different fraction size classes was in the decreasing order: 250 to $2000 \mu \mathrm{m}, 53$ to $250 \mu \mathrm{m},<53 \mu \mathrm{m}$, and with increasing soil depth. Percentage recovery in the 0 - to $25-\mathrm{cm}$ depth demonstrated the effects of tillage (data not shown), as recovery of 250 to $2000 \mu \mathrm{m}$ under both tree species was higher than under the treeless (tilled) pastures. Six et al. (2002a) also demonstrated greater 250 - to $2000-\mu \mathrm{m}$ fraction dry weight recovery in forested and afforested sites compared with tilled agricultural fields in Ohio. They also found the opposite trend in the $<53-\mu \mathrm{m}$ fraction (as is the case in our study), as more silt+clay sized soil fraction was found under traditional row crops as compared with tree-based land uses.

Determination of $\mathrm{C}$ storage in the macroaggregate soil size fraction revealed that birch was better as promoting storage in this fraction than pasture at all soil depths and that pine exceeded pasture in only the deepest sampling depth (Fig. 1). Increased storage of $\mathrm{C}$ in the macroaggregate size is indicative of change in management activities, such as increased inputs from afforestation and cessation of tillage, especially in surface horizons (Six et al., 2000; Allison and Jastrow, 2006; Denef et al., 2007; Tan et al., 2007; D'Angelo et al., 2009). The pasture at Castro de Rey has been tilled three times since establishment in 1995. The continued mechanical disruption of macroaggregate formation under the pasture has led to less storage in this fraction in the plow layer $(0-25 \mathrm{~cm})$. Dry weight recovery of the 250- to $2000-\mu \mathrm{m}$ fraction in the 0 - to $25-\mathrm{cm}$ depth (data not shown) was associated with an increase in SOC in the same fraction in birch but not in pine (Fig. 1). As such, birch (and the understory it promotes) contributes more to the process of macroaggregation than the pine at this soil depth. By maintaining a relatively open canopy, the birch promotes the growth of herbaceous species, which also contribute to SOC storage in the 0 - to $25-\mathrm{cm}$ depth. Allison and Jastrow (2006) found significantly less $\mathrm{C}$ associated with the macroaggregate size class on cultivated pastures as compared with native prairies in Illinois. John et al. (2005) also found more macroaggregate-associated $\mathrm{C}$ in a forested ecosystem than in a grassland or wheat cropped ecosystem in Germany. The organic matter inputs by trees and herbaceous species are the source of macroaggregate formation in the soil. Birch appears to improve SOC storage in the macroaggregate size class, as compared with pine and pasture. Maintaining a relative open canopy in the $3 \times 4 \mathrm{~m}$ spacing promotes the growth of herbaceous species and contributes to significantly greater SOC storage in the $0-$ to $25-\mathrm{cm}$ depth, where most $\mathrm{SOC}$ is stored.

\section{3- to 250- $\mu \mathrm{m}$ and $<53-\mu \mathrm{m}$ Fractions}

Most of the differences in $\mathrm{C}$ storage in the smaller aggregate sizes (53-250 and $<53 \mu \mathrm{m}$ ) were limited to the 0 - to 50-cm depth, where land management changes (tillage) were most prevalent. In the $0-$ to $25-\mathrm{cm}$ depth, tillage in the pasture led to more free (unoccluded) silt+clay sized fraction recovery, which translated into more SOC storage in the pasture as compared with the pine and birch stands (Fig. 1). The smaller aggregates sizes are more stable in the soil, associated with recalcitrant plant/microbial residue and clay minerals, and have $\mathrm{C}$ associated with them that is relatively old (Blanco-Canqui and Lal, 2004). This represents $C$ that was probably in the soil before the 1995 conversion from potato production to pasture and silvopasture. Because the process of macroaggregate formation is significantly reduced in pasture through continued tillage, and while the building blocks of macroaggregates (53- to $250-\mu \mathrm{m}$ and $<53-\mu \mathrm{m}$ aggregates) are present, the formation of new, smaller aggregates is also reduced (Six et al., 2000). Carbon in stable microaggregate and silt+clay size class in the tree-based treatments is likely held in less stable macroaggregates, but the current study cannot validate this 
conjecture. Six et al. (2000) further separated macroaggregates by mechanical disruption and found micro- and silt+clay sized aggregates held within macroaggregates, and, through stable $\mathrm{C}$ isotope studies, have shown that new $\mathrm{C}$ moves from macroaggregates to smaller aggregates over time. This process has been disrupted in the pasture through tillage. These micro- and silt+clay sized stable aggregates represent resistant SOC pools that help to sequester $\mathrm{C}$ over the long term, and, although the amounts sequestered are greater in pasture treatments, the may not truly reflect long-term $\mathrm{C}$ sequestration potential. Further examination of macroaggregate make-up is needed.

\section{Methodology Issues and Management Considerations}

Differences in mineralization of aboveground inputs may help to explain why birch appears to be preferred over pine for sequestering $\mathrm{C}$ in the soil. The presence of slowly decomposing pine needles on the soil surface represents a slower rate of $\mathrm{C}$ input to the soil as compared with quickly decomposing birch leaves (Fernández-Núñez et al., 2010). Pine leaf litter weight ranged from 2.28 to $6.43 \mathrm{Mg}$ dry mater ha ${ }^{-1}$, compared with practically no litter under birch in 2006 (Fernández-Núñez, 2007). Hobbie et al. (2006) found faster decay rates for leaf litter of $B$. pendula as compared with $P$. sylvestris in a common garden plot in Poland. Radiata pine needles have piled up on the understory floor at the Castro de Rey Farm and represent a pool of $\mathrm{C}$ that is relatively unprotected; a fire could oxidize the pine needle $\mathrm{C}$ in a matter of minutes, representing a loss to the system C pool. Although the differences between aboveground and belowground inputs were not considered here, soil inputs from the more slowly mineralizing aboveground leaf litter of radiata pine may not contribute as much to soil $\mathrm{C}$ as faster decomposing birch litter (Fernández-Núñez et al., 2010), which is a possible explanation for the differences in soil $\mathrm{C}$ seen between the two species (Table 3).

Comparison of whole-field $\mathrm{C}$ storage with previously published data on soil $\mathrm{C}$ on this site is difficult because of differences in methodology (data not shown). Fernández-Núñez et al. (2010) used the Saverlandt procedure for determination of total $\mathrm{C}$ to a depth of $25 \mathrm{~cm}$. Additionally, the amount of stoniness (i.e., the fraction of soil that does not pass a $2000-\mu \mathrm{m}$ sieve) was not taken into account. A more shallow sampling depth (0-25 $\mathrm{cm}$ ) would lead to an underestimation of whole-field C storage. In the current study, approximately $78.8 \%$ of the whole soil C was found in the 0 - to $25-\mathrm{cm}$ depth. Also, ignoring stoniness leads to an overestimation of soil C, a concern common to SOC estimation studies (Rodríguez-Murillo, 1997). In the present study, all bulk density estimates were corrected to account for this large, relatively inert, fraction of soil. Estimates of wholefield C storage by Fernández-Núñez et al. (2010) exceed those of the current study (Table 3). Carbon storage is similar to what Nair et al. (2009) estimated for some agroforestry systems in the tropics. Improved fallows, home gardens, and silvopastures in the humid lowland tropics are reported to have similar storage values, whereas many of the other mentioned practices demonstrate lower SOC sequestration potential. In temperate Pennsylvania, the mean estimates for SOC on a northern hardwood forest were much higher than in the current study, with a mean $289 \mathrm{Mg} \mathrm{ha}^{-1}$ (Johnson et al., 2009). Lower estimates of whole-field SOC are found in Stevens and van Wesemael
(2008) for the Belgian Ardennes, from 48.6 to $75.9 \mathrm{Mg} \mathrm{C} \mathrm{ha}^{-1}$, across several varied land uses. Generally though, the wholefield profile sum of SOC to $100 \mathrm{~cm}$ fits well within the range for similar land uses in Spain and worldwide.

Land use in the northwestern province of Galicia, Spain, is undergoing rapid changes as traditional row crops and pastures are being converted to mostly short-rotation, exotic tree plantations, or are abandoned (Zas and Alonso, 2002; Marey-Pérez and Rodríguez-Vicente, 2008). Compared with traditional treeless pastures and row crops, silvopasture may be a preferred land use for a number of reasons other than its potential for $\mathrm{C}$ sequestration in biomass and soils. These reasons include reduced fire risk, the consistent annual or otherwise periodic revenue stream that it can provide, and output of high-quality saw timber (Rigueiro-Rodríguez et al., 2008). The annual production of forage mixed with long-rotation trees provides a stable system of mixed growth characteristics (Sharrow and Ismail, 2004). As pasture lands quickly become forest plantations in Galicia, silvopasture is an alternative land use option that preserves the growth characteristic of fast-growing forage species and the maintenance of animals in the system. Compared with traditional treeless pastures and row crops, silvopasture may be a preferred land use for other environmental benefits, including additional $\mathrm{C}$ sequestration in biomass and soils.

\section{Conclusions}

Silvopasture, as compared with a traditional treeless pasture, is a preferred land usage for the sequestration of $\mathrm{C}$ in deeper soil horizons and in macroaggregates in subsurface horizons. At the Castro de Rey Farm simulated silvopasture experiment, birch in the $3 \times 4 \mathrm{~m}$ spacing with no fertilizer was shown to be a better improver of SOC storage in the whole soil and macroaggregate size fraction when compared to other treatment combinations. Both tree-based systems increased SOC storage in the deeper soil profile $(75-100 \mathrm{~cm})$, as compared with the treeless pasture. The tree and forage components input $\mathrm{C}$ to the deep and subsurface soils, respectively, and, combined in silvopasture, is a preferred method for improving SOC storage in Atlantic Spain. Although this study has exclusively considered soil $\mathrm{C}$ resources, when one includes the aboveground and belowground $\mathrm{C}$ storage in biomass, silvopasture is a preferred land use choice when $\mathrm{C}$ sequestration is a management goal. Fire incidence is reduced in silvopasture (a major advantage over pure plantations), and the tree and forage components each represent significant inputs to SOC storage.

The development and promotion of new silvopastures in Atlantic Spain will improve SOC storage over current land uses. Exotic pine and eucalyptus plantations occupy large areas of the landscape for pulp-wood production in Galicia, Spain. As a land use alternative, silvopasture is being promoted to lessen fire risk, to maintain animal production, and to meet the needs for high-quality saw timber. Silvopasture, as compared with treeless pasture, has been shown to preferentially sequester SOC, with significant increases at the deeper soil depths examined. Spain has considerable interest in preserving and promoting these systems for a host of benefits, including enhancement of SOC storage. 


\section{References}

Allison, S.D., and J.D. Jastrow. 2006. Activities of extracellular enzymes in physically isolated fraction of restored grassland soils. Soil Biol. Biochem. 38:3245-3256.

Balesdent, J., E. Bersnard, D. Arrouays, and C. Chenu. 1998. The dynamics of carbon in particle-size fractions of soil in a forest cultivation sequence. Plant Soil 201:49-57.

Blanco-Canqui, H., and R. Lal. 2004. Mechanisms of carbon sequestration in soil aggregates. Crit. Rev. Plant Sci. 23:481-504.

Christensen, B.T. 2001. Physical fractionation of soil and structural and functional complexity in organic matter turnover. Eur. J. Soil Sci. 52:345-353.

Corre, M.D., R.R. Schnabel, and J.A. Shaffer. 1999. Evaluation of soil organic carbon under forests, cool-season and warm season grasses in the northeastern US. Soil Biol. Biochem. 31:1531-1539.

D'Angelo, E., C.A. Kovzelove, and A.D. Karathanasis. 2009. Carbon sequestration processes in temperate soils with different chemical properties and management histories. Soil Sci. 174:45-55.

Denef, K., L. Zotarelli, R.M. Boddey, and J. Six. 2007. Microaggregate-associated carbon as a diagnostic fraction for management-induced changes in soil organic carbon in two oxisols. Soil Biol. Biochem. 39:1165-1172.

Elliott, E.T. 1986. Aggregate structure and carbon, nitrogen, and phosphorus in native and cultivated soils. Soil Sci. Soc. Am. J. 50:627-633.

European Environment Agency. 2006. European forest types: Categories and types for sustainable forest management reporting and policy. EEA Technical Report No. 9, Copenhagen, Denmark.

Fernández-Núńez, E. 2007. Sistemas silvopastorales establecidos con Pinus radiata D. Don y Betula alba L. en Galicia: Productividad, biodiversidad y sumideros de carbono. Ph.D. thesis. Universidad de Santiago de Compostela, Escuela Politécnica Superior, Lugo, Spain.

Fernández-Núñez, E., A. Rigueiro-Rodríguez, and M.R. Mosquera-Losada. 2010. Carbon allocation dynamics one decade after planting of afforested land with Pinus radiata D. Don and Betula alba L. developed under two stand densities in NW Spain. Ecol. Eng. 36:876-890.

Guo, L.B., and R.M. Gifford. 2002. Soil carbon stocks and land use change: A meta analysis. Glob. Change Biol. 8:345-360.

Guo, L.B., M. Wang, and R.M. Gifford. 2007. The changes of soil carbon stocks and fine root dynamics after land use change from a native pasture to a pine plantation. Plant Soil 299:251-262.

Haile, S.G., P.K.R. Nair, and V.D. Nair. 2008. Carbon storage of different soil-size fractions in Florida silvopastoral systems. J. Environ. Qual. 27:1789-1797.

Haile, S.G., V.D. Nair, and P.K.R. Nair. 2010. Contribution of trees to soil carbon sequestration in silvopastoral systems of Florida. Glob. Change Biol. 16:427-438.

Hobbie, S.E., P.B. Reich, J. Oleksyn, M. Ogdahl, R. Zytkowiak, C. Hale, and P. Karolewski. 2006. Tree species effects on decomposition and forest floor dynamics in a common garden. Ecology 87:2287-2297.

Jastrow, J.D., and R.M. Miller. 1998. Soil aggregate stabilization and carbon sequestration: Feedbacks through organo-mineral associations. p. $207-$ 224. In R. Lal and J.M. Kimble (ed.) Soil processes and the carbon cycle. CRC Press, New York.

Jobbagy, E.G., and R.B. Jackson. 2000. The vertical distribution of soil organic carbon and its relation to climate and vegetation. Ecol. Appl. 10:423-436.

John, B., T. Yamashita, B. Ludwig, and H. Flessa. 2005. Storage of organic carbon in aggregate and density fractions of silty soils under different types of land use. Geoderma 128:63-79.

Johnson, K.D., F.N. Scatena, A.H. Johnson, and Y. Pan. 2009. Controls of soil organic matter content within a northern hardwood forest. Geoderma 148:346-356.

Kasel, S., and L.T. Bennett. 2007. Land-use history, forest conversion, and soil organic carbon in pine plantations and native forests of south eastern Australia. Geoderma 137:401-413.

Lal, R. 2004. Soil carbon sequestration impacts on global climate change and food security. Science 304:1623-1627.
Marey-Pérez, M.F., and V. Rodríguez-Vicente. 2008. Forest transition in northern Spain: Local responses on large scale programmes of field-afforestation. Land use policy 26:139-156.

Moreno, G., J.J. Obrador, E. Cubera, and C. Dupraz. 2005. Fine root distribution in dehesas of central-western Spain. Plant Soil 277:153-162.

Mosquera-Losada, M.R., E. Fernández-Núnez, and A. Rigueiro-Rodríguez. 2006. Pasture, tree and soil evolution in silvopastoral systems of Atlantic Europe. For. Ecol. Manage. 232:135-145.

Nair, P.K.R., B.M. Kumar, and V.D. Nair. 2009. Agroforestry as a strategy for carbon sequestration. J. Plant Nutr. Soil Sci. 172:10-23.

Nair, P.K.R., V.D. Nair, B.M. Kumar, and J.M. Showalter. 2010. Carbon sequestration in agroforestry systems. Adv. Agron. 108:237-307.

Parton, W.J., D.S. Schimel, C.V. Cole, and D.S. Ojima. 1987. Analysis of factors controlling soil organic matter levels in Great Plains grasslands. Soil Sci. Soc. Am. J. 51:1173-1179.

Paul, K.I., P.J. Polgase, J.G. Nyakuengama, and P.K. Khanna. 2002. Change in soil carbon following afforestation. For. Ecol. Manage. 168:241-257.

Rigueiro-Rodríguez, A., J. McAdam, and M.R. Mosquera-Losada. 2008. Agroforestry in Europe. Advances in Agroforestry Vol. 6. Springer, New York.

Rigueiro-Rodríguez, A., M.R. Mosquera-Losada, and E. Gatica-Trabanini. 2000. Pasture production and tree growth in a young pine plantation fertilized with inorganic fertilizers and milk sewage in northwestern Spain. Agrofor. Syst. 48:245-256.

Rodríguez-Murillo, J.C. 1997. Temporal variations in the carbon budget of forest ecosystems in Spain. Ecol. Appl. 7:461-469.

Rodríguez-Murillo, J.C. 2001. Organic carbon content under different types of land use and soil in peninsular Spain. Biol. Fertil. Soils 33:53-61.

Saha, S.K., P.K.R. Nair, V.D. Nair, and B.M. Kumar. 2010. Carbon storage in relation to soil size-fractions under some tropical tree-based land-use systems. Plant Soil 328:433-446.

Sharrow, S.H., and S. Ismail. 2004. Carbon and nitrogen storage in agroforests, tree plantations, and pastures in western Oregon, USA. Agrofor. Syst. 60:123-130.

Schimel, D.S., B.H. Braswell, E.A. Holland, R. Mckeown, D.S. Ojima, T.H. Painter, W.J. Parton, and A.R. Townsend. 1994. Climatic, edaphic, and biotic controls over storage and turnover of carbon in soils. Global Biogeochem. Cycles 8:279-293.

Six, J., E.T. Elliott, and K. Paustian. 2000. Soil macroaggregate turnover and microaggregate formation: A mechanism for $\mathrm{C}$ sequestration under notillage agriculture. Soil Biol. Biochem. 32:2099-2103.

Six, J., P. Callewaert, S. Lenders, S. De Gryze, S.J. Morris, E.G. Gregorich, E.A. Paul, and K. Paustian. 2002a. Measuring and understanding carbon storage in afforested soils by physical fractionation. Soil Sci. Soc. Am. J. 66:1981-1987.

Six, J., R.T. Conant, E.A. Paul, and K. Paustian. 2002b. Stabilization mechanisms of soil organic matter: Implications for C-saturation of soils. Plant Soil 241:155-176.

Soil Survey Staff. 2004. Particle size analysis method. p. 41. In R. Burt (ed.) Soil survey laboratory methods manual. Soil Survey Investigations Rep. 42, Version 4. USDA-NRCS, National Soil Survey Center, Lincoln, NE.

Stevens, A., and B. van Wesemael. 2008. Soil organic carbon stock in the Beligian Ardennes as affected by afforestation and deforestation from 1868-2005. For. Ecol. Manage. 256:1527-1539.

Takimoto, A., V.D. Nair, and P.K.R. Nair. 2009. Contribution of trees to soil carbon sequestration under agroforestry systems in the Western Sahel. Agrofor. Syst. 76:11-25.

Tan, Z., R. Lal, L. Owens, and R.C. Izaurralde. 2007. Distribution of light and heavy fractions of soil organic carbon as related to land use and tillage practice. Soil Tillage Res. 92:53-59.

Theodorou, C., and G.D. Bowen. 1990. Effects of fertilizer on litterfall and N and $\mathrm{P}$ release from decomposing litter in a Pinus radiata plantation. For. Ecol. Manage. 32:87-102.

Zas, R., and M. Alonso. 2002. Unnderstory vegetation as indicators of soil characteristics in northwest Spain. For. Ecol. Manage. 171:101-111. 